\title{
Natural History, Clinical Manifestations, and Pathogenesis of Hepatitis E Virus Genotype 1 and 2 Infections
}

\author{
Rakesh Aggarwal and Amit Goel \\ Department of Gastroenterology, Sanjay Gandhi Postgraduate Institute of Medical Sciences, \\ Lucknow 226014, India \\ Correspondence: aggarwal.ra@gmail.com
}

\begin{abstract}
Infection with genotype 1 or 2 hepatitis $\mathrm{E}$ virus (HEV) results primarily from human-to-human transmission through the fecal-oral route in low-resource countries. It presents primarily as "acute viral hepatitis" syndrome, usually a self-limiting illness. A few cases progress to acute liver failure, a serious illness with high fatality. Clinical disease is infrequent among children. Infection during pregnancy is associated with a higher risk of symptomatic disease, severe liver injury, and mortality. Severe disease is also encountered in persons with preexisting chronic liver disease. Some cases have associated extrahepatic features, particularly acute pancreatitis and neurological manifestations. Chronic infection appears to be extremely infrequent with these HEV genotypes. The exact pathogenesis of liver injury remains unknown, although the host immune response appears to be important for viral clearance as well as for induction of liver injury. Hormonal and immune factors appear to be responsible for the severe disease during pregnancy.
\end{abstract}

$\mathrm{H}^{2}$ epatitis E virus (HEV) consists of small virions with a positive- and single-stranded $\sim 7.2-\mathrm{kb}$ RNA genome and predominantly fecal-oral transmission. Traditionally, isolates associated from humans have been categorized into four genotypes, namely, genotype (gt)1 to gt4 (Lu et al. 2006; Zhai et al. 2006), although occasional cases of gt7 infections have been reported in recent years from the Mediterranean region (Lee et al. 2016). Human HEV infection is associated with two distinct epidemiological and clinical patterns of disease, with the illnesses associated with gt 1 and gt $2 \mathrm{HEV}$ infection differing markedly from those associated with gt3 and gt4 HEV infection (Aggarwal and Naik
2009; Aggarwal and Goel 2016; Goel and Aggarwal 2016; see Kamar and Pischke 2018).

The disease caused by infection with gt 1 and gt2 HEV is endemic, and often hyperendemic, in parts of the world where water quality and sanitation facilities are suboptimal, allowing frequent contamination of drinking water supplies with human fecal material. Thus, these infections have been reported most frequently from parts of Asia (in particular South Asia, Central Asia), the Middle East, and the Mediterranean region, and Africa, and less frequently from South America (Aggarwal and Naik 2009). In comparison, disease caused by infection with these genotypes has been reported quite infre-

Editors: Stanley M. Lemon and Christopher Walker

Additional Perspectives on Enteric Hepatitis Viruses available at www.perspectivesinmedicine.org

Copyright (C) 2019 Cold Spring Harbor Laboratory Press; all rights reserved; doi: 10.1101/cshperspect.a032136

Cite this article as Cold Spring Harb Perspect Med 2019;9:a032136 
quently from Southeast Asia. In Europe, the United States, Canada, and Australia, most of the infections with these genotypes have been among those with recent travel to Asia and Africa (Kamar et al. 2012).

Infection with gt1 HEV is much more prevalent than that with gt $2 \mathrm{HEV}$. Further, the former genotype is geographically more widespread, having been reported from most parts of Asia and Africa and from Latin America (Aggarwal and Naik 2009). In contrast, reports of gt2 HEV have been limited to Mexico, where it was first identified in the 1980s (Velazquez et al. 1990; Huang et al. 1992) but has not been reported thereafter, and to some countries in West Africa, such as Central African Republic, Chad, Namibia, and Nigeria (Kim et al. 2014).

Both of these HEV genotypes appear to have a limited host range, causing natural infection only in humans and being incapable of causing infection in experimentally inoculated pigs (Meng et al. 1998). Thus, these are believed to spread only through human-to-human transmission. In contrast, g3 and gt 4 $\mathrm{HEV}$ are widely prevalent among several mammalian species, with occasional zoonotic transmission to humans (Meng 2013).

\section{OVERVIEW OF NATURAL HISTORY OF GENOTYPE 1 AND 2 HEV INFECTION}

A large proportion of infections with gt1 or gt2 $\mathrm{HEV}$ are subclinical and go unnoticed. This assumption is supported by detection of anti-HEV IgG in several persons who have never had jaundice in the populations where these genotypes are frequent, and by moderate to high seroprevalence of these antibodies in some areas where clinical disease is infrequent (e.g., Egypt) (Fix et al. 2000; Stoszek et al. 2006b; Aggarwal 2010). Most cases that come to clinical recognition present as acute viral hepatitis (AVH) (also known as "acute jaundice syndrome") and have a self-limited course lasting a few weeks. Occasional cases progress to serious disease, known as acute liver failure (ALF), with high mortality (Aggarwal 2011, 2013). When HEV infection occurs in a pregnant woman, the risk of clinical disease and of ALF is quite high (Khuroo et al. 1981).
Persistent or chronic infection, well known with gt 3 and gt 4 , is either nonexistent or fairly infrequent with gt 1 and gt $2 \mathrm{HEV}$ infection (for details of gt 3 and gt 4 pathogenesis, see Kamar and Pischke 2018).

These various forms of infection and disease associated with gt 1 and gt $2 \mathrm{HEV}$ infection are discussed in detail in the following section on clinical manifestations.

\section{CLINICAL MANIFESTATIONS}

HEV gt 1 and gt 2 infections cause disease in the form of outbreaks and as sporadic cases (Aggarwal 2011, 2013). The clinical manifestations are similar for sporadic cases and the cases occurring during disease outbreaks and for infection with gt 1 and gt2 $\mathrm{HEV}$, although data for gt2 virus are quite limited.

The clinical consequences of infection with these genotypes are related primarily to acute inflammation of the liver. A small proportion of infections present with injury to other body organs, often in conjunction with liver disease.

\section{Liver Disease}

Severity of liver injury during infection with gt 1 or gt $2 \mathrm{HEV}$ infection can vary markedly. The clinical syndrome most frequently identified in persons with these infections is known as "acute viral hepatitis.” The illness is usually self-resolving, with spontaneous and complete recovery in a few weeks. However, a small proportion of patients develop the more severe ALF illness (Aggarwal 2011, 2013).

During large outbreaks of hepatitis $\mathrm{E}$ in South Asia, young people aged 10-40 years have been found to be the most frequently affected (Viswanathan 1957; Khuroo 1980; Naik et al. 1992). In comparison, the number of cases among children and the elderly is much fewer than would be expected based on the age distribution of the population. The disease is somewhat more frequent among men than among women. These features are also identified among sporadic cases with hepatitis $\mathrm{E}$ in the geographical areas in which gt 1 and gt 2 are prevalent. The predilection for males is believed 
to be related to a greater risk of exposure to contaminated water as a result of their spending more time on outdoor activities. The relative sparing of the elderly may also be explained on a similar basis. However, the relative sparing of children is possibly related not to a lower risk of infection, but to a lower risk of disease among those with infection (Patel et al. 2015). This hypothesis is based on frequent occurrence of other water- and foodborne illnesses among children in these geographical areas, as well as relatively low frequency of disease among children during hepatitis E outbreaks in humanitarian emergencies in Africa where very high attack rates have been observed in adults suggesting heavy water contamination (Teshale et al. 2010).

\section{Acute Icteric Hepatitis}

Acute icteric hepatitis syndrome associated with gt1 or gt $2 \mathrm{HEV}$ infection is similar to that ob- served in infection with other hepatotropic viruses. The syndrome typically runs a triphasic course: prodromal, icteric, and convalescent phases (Table 1) (Viswanathan and Sidhu 1957), although the first phase may not be discernible in some patients.

The illness starts with a "prodrome" (or prodromal phase) characterized by a variable combination of nonspecific symptoms, including loss of appetite, low-grade fever, intense nausea, occasional vomiting, aversion to smoking, malaise, body ache, etc. This illness often resembles that of the usual viral "flu." Patients may also have mild right or midline upper abdominal discomfort, possibly caused by stretching of the liver capsule as a result of inflammation (Aggarwal 2011). Some may notice a deeper color of urine, a lighter color of stools, or itching. During a large outbreak in Kashmir, the prodromal phase was seen in $61 \%$ of cases and lasted for 1-10 (mean 3.5) days (Khuroo 1980). The most frequent pro-

Table 1. Clinical and biochemical features during three phases of acute icteric hepatitis caused by genotype 1 or 2 hepatitis E virus (HEV) infection

\begin{tabular}{|c|c|c|c|}
\hline Phase & Symptoms and other features & $\begin{array}{c}\text { Findings on clinical } \\
\text { examination }\end{array}$ & Laboratory findings \\
\hline $\begin{array}{l}\text { Prodromal } \\
\text { phase }\end{array}$ & $\begin{array}{l}\text { Malaise, myalgias, fatigue, } \\
\text { low-grade fever, arthralgias } \\
\text { Anorexia, aversion to food } \\
\text { Nausea, vomiting } \\
\text { Abdominal discomfort, right } \\
\text { upper quadrant pain } \\
\text { Symptoms last for a few days }\end{array}$ & $\begin{array}{l}\text { Mild, soft hepatomegaly } \\
\text { Mild tenderness in right } \\
\text { upper quadrant of the } \\
\text { abdomen }\end{array}$ & $\begin{array}{l}\text { Normal serum bilirubin } \\
\text { Marked elevation (usually }>10 \text { - } \\
\text { fold) of serum alanine } \\
\text { aminotransferase (ALT) and } \\
\text { aspartate aminotransferase } \\
\text { (AST) levels } \\
\text { Normal to mildly elevated serum } \\
\text { alkaline phosphatase levels }\end{array}$ \\
\hline Icteric phase & $\begin{array}{l}\text { Yellow discoloration of skin, } \\
\text { eyes and urine ( jaundice, } \\
\text { or icterus) } \\
\text { Improvement of systemic } \\
\text { symptoms and appetite } \\
\text { Improving well-being } \\
\text { In some cases, mild itching } \\
\text { and light-colored stools } \\
\text { Lasts for a few weeks }\end{array}$ & $\begin{array}{l}\text { Icterus } \\
\text { Mild, soft hepatomegaly } \\
\text { Occasional mild, soft, } \\
\text { nontender palpable } \\
\text { spleen }\end{array}$ & $\begin{array}{l}\text { Elevated serum bilirubin, } \\
\text { predominantly conjugated } \\
\text { Moderate elevation of serum } \\
\text { ALT and AST levels, although } \\
\text { usually lower than in the } \\
\text { prodromal phase } \\
\text { Normal to mildly elevated serum } \\
\text { alkaline phosphatase levels }\end{array}$ \\
\hline $\begin{array}{l}\text { Convalescent } \\
\text { phase }\end{array}$ & $\begin{array}{l}\text { Gradual and nearly complete } \\
\text { recovery in symptoms, } \\
\text { although mild icterus and } \\
\text { fatigue may persist for a } \\
\text { few weeks } \\
\text { Occasional patients develop } \\
\text { prolonged cholestasis }\end{array}$ & $\begin{array}{l}\text { Icterus: moderate-to- } \\
\text { mild, but gradually } \\
\text { improving } \\
\text { Normal urine color } \\
\text { Regression of liver and } \\
\text { spleen size to normal }\end{array}$ & $\begin{array}{l}\text { Declining serum bilirubin levels, } \\
\text { returning to near normal } \\
\text { Normal or slightly elevated } \\
\text { serum ALT and AST levels } \\
\text { Normal alkaline phosphatase } \\
\text { levels }\end{array}$ \\
\hline
\end{tabular}


dromal symptoms were anorexia (79\%), dark urine $(58 \%)$, nausea and vomiting (46\%), fever (44\%), epigastric pain (41\%), followed by cholestatic symptoms (i.e., clay stools and itching) in $20 \%$. Also, in other large outbreaks, similar prodromal symptoms have been reported in comparable frequencies (Tsega et al. 1991; Aggarwal 2011). Blood tests reveal marked elevation of serum levels of aminotransferase enzymes (alanine aminotransferase [ALT] and aspartate aminotransferase $[\mathrm{AST}]$ ), with normal or mildly elevated serum bilirubin levels (Table 1).

The prodromal phase is replaced in a few days by the "icteric" phase, which is characterized by the appearance of icterus (or jaundice: yellowish discoloration of the skin and sclerae of the eyes). With the onset of this phase, fever, nausea, and other prodromal symptoms start regressing, and the appetite begins to improve. Clinical examination is generally unremarkable except for jaundice (variable in degree from mild to severe), a slightly enlarged, and mildly tender liver, accompanied in a small proportion of patients by a soft, nontender, slightly enlarged spleen. Serum bilirubin levels are high but the serum levels of liver enzymes tend to be lower than during the prodrome.

In a large majority of cases, the jaundice persists for 2-4 weeks, followed by spontaneous and gradual regression (the "convalescent" phase). During this period and for a few days to weeks after the disappearance of jaundice, low-grade nonspecific symptoms may persist.

The duration of jaundice can be highly variable, lasting for several weeks to months in some patients. Furthermore, in such patients, "cholestatic symptoms" (itching, clay stools, etc.) may be particularly prominent. This "prolonged cholestasis" is described in greater detail later.

\section{Acute Liver Failure}

A small proportion (usually $<1 \%$ ) of patients with AVH-like illness associated with gt1 and gt2 HEV infection progress to develop ALF (also known as acute hepatic failure, fulminant liver failure, fulminant hepatic failure) (Viswanathan and Sidhu 1957; Aggarwal 2011). The illness generally begins similarly to the usual acute icteric hepatitis, but then progresses and the patient develops features of liver failure, namely, hepatic encephalopathy and prothrombin time prolongation. This syndrome is believed to arise from sudden and massive loss of liver cells, leading to marked reduction in the liver's detoxification and synthetic ability. ALF is frequently associated with marked swelling of the brain (cerebral edema), which further adds to the neurological complications.

Clinical examination notably reveals an alteration in sensorium and/or evidence of bleeding from various body sites. In patients with ALF, liver size is usually small, reflecting a massive necrosis of liver cells. In addition, signs of increased intracranial pressure are often present. A minority of patients have ascites. Biochemical tests show features of reduced synthesis of body proteins in the liver, in the form of hypoalbuminemia and prolongation of tests that measure coagulation.

Development of ALF heralds a major worsening of outcome with a high mortality rate. Patients with ALF need management in an intensive care unit with facilities for liver transplantation if required. ALF appears to be more common in gt1 or gt2 HEV infections than gt 3 or gt4 infections. However, the manifestations, outcome, and treatment of ALF caused by gt 1 or gt2 HEV infection are fairly similar to that observed with other hepatotropic viruses.

In South Asia, where gt1 and gt2 HEV are hyperendemic, HEV is the most common cause of ALF among adults (Acharya et al. 2000; Khuroo and Kamili 2003). In these cases, the mortality rates are in the range of $40 \%$ to $60 \%$ (Khuroo and Kamili 2003; Bhatia et al. 2008).

\section{Anicteric Hepatitis}

Although acute icteric hepatitis is the most well recognized clinical form of gt1 or gt2 HEV infection, it appears that this is not the most frequent clinical consequence of such infection. A large proportion of such infections are associated with a milder liver injury with "anicteric hepatitis" - with asymptomatic, transient elevation of serum levels of aminotransferase enzymes, with either no or minimal elevation of serum 
bilirubin. In such cases, HEV infection and liver injury often go undetected, unless liver function tests are performed either for non-liver-specific symptoms or for another reason, leading to a search for the cause of abnormal test results. Alternatively, an astute physician may suspect this condition among persons with prodromal symptoms but no jaundice residing in an area with an ongoing disease outbreak.

\section{Extrahepatic Manifestations}

Although liver is the primary organ affected during HEV infection, other organs systems can occasionally be involved (Woolson et al. 2014; Bazerbachi et al. 2016; Kamar et al. 2016). Extrahepatic involvement is usually associated with liver disease. Some cases of extrahepatic manifestations with serological evidence of $\mathrm{HEV}$ infection in the absence of liver disease have been reported; however, in such cases, the role of $\mathrm{HEV}$ infection in causing these conditions is difficult to ascertain.

In geographic regions in which gt 1 or $2 \mathrm{HEV}$ are predominant, the most common body organs or sites affected as part of hepatitis $\mathrm{E}$ have been pancreas, nervous system, bone marrow, and kidney (Aggarwal 2013; Bazerbachi et al. 2016). In contrast to developed countries where $\mathrm{HEV}$ gt3 HEV predominates, the evidence of HEV gt1 infection in most cases has come from the presence of IgM anti-HEV antibodies and not from detection of HEV RNA.

\section{Acute Pancreatitis}

Several case reports and case series of acute pancreatitis (AP) following uncomplicated acute hepatitis or ALF caused by HEV infection have been published. The overall risk of AP in HEV infection is small. Importantly, a large majority of cases of AP following HEV infection have been reported from geographical areas in which gt1 $\mathrm{HEV}$ is predominant (Mishra et al. 1999; Bhagat et al. 2008; Raj et al. 2015) or among travelers to these regions (Jaroszewicz et al. 2005). No autochthonous cases have been reported from areas in which gt $3 \mathrm{HEV}$ is prevalent. There are no data on $\mathrm{HEV}$-related AP from areas where gt $2 \mathrm{HEV}$ is prevalent; however, this may reflect a general paucity of publications from these areas.

HEV-related AP predominantly occurs in young patients with HEV-induced ALF. The patients with $\mathrm{HEV}$-associated pancreatitis have been more often men, although this could reflect better health care access among men in developing countries where such cases occur. AP often appears $\sim 10$ days after the onset of liver disease. The severity of pancreatic disease has been variable but is usually followed by uneventful recovery (Raj et al. 2015).

\section{Neurological Involvement}

A wide variety of manifestations related to the central and the peripheral nervous system have been reported in association with HEV infection (Kamar et al. 2011; Dalton et al. 2016). However, in contrast to pancreatitis, the number of cases of neurological involvement associated with HEV infection from areas with gt1 predominance has been much smaller than those from gt3 areas (Bazerbachi et al. 2016). Also, the spectrum of abnormalities reported as being associated with HEV infection has been narrower in the areas with gt1 HEV (Table 2).

Table 2. Non-hepatic manifestations of genotype 1 or 2 hepatitis E virus infection

Gastrointestinal tract
Acute pancreatitis
Neurological involvement
Peripheral nervous system
Guillain-Barré syndrome
Nerve palsies: oculomotor nerve, facial nerve
Central nervous system
Meningoencephalitis
Aseptic meningitis
Pseudotumor cerebri
Hematological manifestations
Hemolysis
Thrombocytopenia
Hemophagocytic syndrome
Aplastic anemia
Renal manifestations
Membranous glomerulonephritis
Autoimmune phenomena
Henoch-Schönlein purpura
Myocarditis


R. Aggarwal and A. Goel

\section{Hematological Involvement}

The most common hematological manifestation reported in patients with acute hepatitis $\mathrm{E}$ has been acute hemolysis. Many of these patients have also had deficiency of glucose 6-phosphate dehydrogenase, and HEV infection appears to merely exacerbate that condition (Abid and Khan 2002). The hemolysis manifests as deep jaundice and renal dysfunction.

Other hematological manifestations observed in persons with HEV infection in disease-hyperendemic areas have been thrombocytopenia (Singh and Gangappa 2007), bone marrow aplasia (Mishra et al. 2007), and secondary hemophagocytic syndrome.

\section{Other Extrahepatic Manifestations}

Occasional cases of myocarditis (Kochar et al. 2016), Henoch-Schönlein purpura, and renal involvement (Ali et al. 2001) have also been reported from areas where gt1 $\mathrm{HEV}$ is predominant. Essential mixed cryoglobulinemia, which has been reported in association with gt3 HEV infection (Bazerbachi et al. 2017), has not been reported in association with gt $1 \mathrm{HEV}$ infection.

\section{Special Situations \\ HEV Infection in Pregnant Women and Neonates}

gt 1 or gt $2 \mathrm{HEV}$ infection in pregnant women is more likely to be associated with clinical disease and, in particular, severe manifestations than in nonpregnant women or men. This association was clearly shown during an epidemic in Kashmir, India, where the attack rate of icteric hepatitis in pregnant women $(17.3 \%)$ was found to be much higher than those in nonpregnant women $(2.1 \%)$ or men $(2.8 \%)$. The risk is the highest during the second and third trimesters of pregnancy (Khuroo et al. 1981).

Among patients with AVH-E, the clinical features in pregnant women are not different from those in nonpregnant women. However, among patients with symptomatic hepatitis E, pregnant women are at greater risk of progres- sion to ALF. In the Kashmir epidemic, 22.2\% of pregnant women affected during the outbreak had ALF, compared with $0 \%$ and $2.8 \%$ of the nonpregnant women and men, respectively (Khuroo et al. 1981).

Once ALF develops, the mortality rates appear to be similar among pregnant and nonpregnant women (Bhatia et al. 2008). However, because pregnant women have a higher risk of developing ALF, hepatitis $\mathrm{E}$ in pregnancy is associated with high overall case-fatality rates, which may reach up to $\sim 25 \%$.

The association of HEV with pregnant women is primarily reported from countries where gt1 is predominant (Tsega et al. 1992; Pérez-Gracia et al. 2017). Except for a few case reports (Anty et al. 2012; Tabatabai et al. 2014), this association of pregnancy with hepatitis $\mathrm{E}$ has not been identified in geographical areas where gt 3 and gt 4 are prevalent (Renou et al. 2014). Also, in Egypt, even though the circulating HEV isolates belong to gt1, pregnant women do not have severe forms of disease (Stoszek et al. 2006a).

Hepatitis E during late pregnancy is associated with increased risk of premature delivery and increased fetal loss. The newborns have low birth weight, hypoglycemia, ill health, and a higher neonatal mortality (Khuroo et al. 1995; Patra et al. 2007; Krain et al. 2014).

\section{HEV Superinfection in Patients with Chronic Liver Disease}

In persons with chronic liver disease, in particular cirrhosis, who have a reduced liver functional reserve, any superadded liver injury, irrespective of its cause, may be expected to compromise the liver function further and result in liver failure. In such persons, even mild liver injury caused by HEV infection, which may have been insignificant in a healthy person, can be expected to result in liver decompensation.

In areas where gt $1 \mathrm{HEV}$ is hyperendemic, several reports have implicated sporadic infections with $\mathrm{HEV}$ as a cause of deterioration of liver function in patients with preexisting chronic liver disease (Kumar et al. 2004; Kumar Acharya et al. 2007; Radha Krishna et al. 
Manifestations and Pathogenesis of HEV 1 and 2 Infections

2009). HEV infection in such persons usually begins as an illness resembling typical acute hepatitis, to be followed in a few days by the onset of ascites, encephalopathy, or both, suggesting decompensated liver disease. Differentiation of this syndrome from ALF caused by HEV infection usually depends on clinical, imaging, or endoscopic findings characteristic of liver cirrhosis or portal hypertension. The mortality rate of such illness is higher than that observed following $\mathrm{HEV}$ infection in previously healthy people.

\section{Prolonged Cholestasis}

In the usual course of acute hepatitis E during the convalescent phase, the symptoms gradually resolve and liver function tests return to normal. However, in some patients, a phase of prominent cholestasis supervenes. This is associated with deep icterus, often associated with itching and moderately elevated serum levels of alkaline phosphatase with normal or only mildly elevated serum transaminase levels (Aggarwal 2011, 2013). Itching can at times be intense, impairing sleep, work performance, and quality of life, and may be unresponsive to various nonpharmacologic measures and drugs. This phase usually lasts for 6-8 weeks but may sometimes be longer. The illness may superficially resemble extrahepatic biliary obstruction, which, however, is ruled out by imaging techniques such as ultrasound.

Prolonged cholestasis appears not to result in any long-term adverse effect on liver function (Mechnik et al. 2001). Spontaneous and complete recovery, over weeks to months, is the rule. Patients need counseling, reassurance, general antipruritic measures, topical emollients, and oral antipruritic medications while awaiting natural recovery.

Because of its low frequency and benign course, the available literature on actual frequency, risk factors for its occurrence, or the underlying mechanism(s) of this form of illness is quite limited. Increased opioidergic tone has been proposed as one of the mechanisms, and opioid antagonists have been tried as treatment (Joshi et al. 2009).

\section{Chronic Hepatitis E}

Some people infected with gt 3 or gt $4 \mathrm{HEV}$ fail to clear the virus, and go on to develop chronic HEV infection (Kamar et al. 2008), defined as persistent infection for more than 6 months (see Kamar and Pischke 2018). This outcome has been observed exclusively among those with impaired immune response, particularly those receiving immunosuppressive drugs following organ transplantation (Kamar et al. 2008) and, less frequently, among those with human immunodeficiency virus infection (Dalton et al. 2009), hematological malignancies (Ollier et al. 2009), or following administration of tumor necrosis factor $\alpha$ antagonists (van Bijnen et al. 2017). Such infection is associated with chronic liver inflammation and injury, and may progress to cirrhosis.

The reports of chronic hepatitis $\mathrm{E}$ have been mostly in people with gt $3 \mathrm{HEV}$ infection, and occasionally in those with gt4 HEV infection (Kamar et al. 2012). Published data on chronic $\mathrm{HEV}$ infection with gt1 HEV are limited to a child previously treated for acute leukemia who had prolonged liver dysfunction and was found to have prolonged HEV viremia, albeit for only 3 months, before antiviral treatment was begun (Singh et al. 2016). Two large studies of Indian renal transplant recipients, including those with unexplained elevation of transaminase, have failed to show evidence of chronic HEV infection (Naik et al. 2013; Munjal et al. 2014). There is no report of chronic infection with gt $2 \mathrm{HEV}$. These findings in the face of the knowledge that global burden of gt1 and gt2 $\mathrm{HEV}$ infections is much higher than that caused by gt 3 or gt $4 \mathrm{HEV}$ indicate that chronic infection with gt 1 or gt $2 \mathrm{HEV}$ either does not occur or is very infrequent.

\section{PATHOGENESIS}

Our current understanding of the pathogenesis of HEV infection, based mostly on data from animal models and cell culture systems, with some additional information from humans, is relatively incomplete (Wedemeyer et al. 2013). In experimental models, gt 1 and gt $2 \mathrm{HEV}$ have 
been shown to cause infection in various nonhuman primates, but not in pigs; this is in contrast to gt 3 and gt4, which are known to naturally infect both pigs and humans, and have been shown to be capable of experimental transmission to nonhuman primates.

The virus enters the host through the gastrointestinal tract, via contaminated food or water. Infection in humans is followed by an incubation period of 2 to 10 weeks (Viswanathan 1957). During this period, the virus crosses the intestinal mucosa and reaches the liver via the portal circulation. It remains unclear whether it also undergoes multiplication in the enterocytes before entry into the circulation.

In the liver, the virus enters and multiplies in the hepatocytes, the primary site of infection. In studies with monkeys, viral replication in hepatocytes appears $\sim 7$ days after parenteral inoculation and affects up to $70 \%-90 \%$ of hepatocytes (Ticehurst et al. 1992). This replication is believed to proceed to a stage of hepatocyte injury, leading eventually, in humans, to appearance of a clinical illness after an average incubation period of 3 weeks (range 2-10). Viremia appears several days before the onset of symptoms (Fig. 1) and reaches a peak with that of serum transaminase levels, persists for 2-3 weeks thereafter, and is associated with fecal HEV excretion (Tsarev et al. 1992; Aggarwal et al. 2000). The fecal excretion lasts for somewhat longer than viremia.

In cell culture studies, HEV has been shown to lack a cytopathic effect (Tanaka et al. 2007; Takahashi et al. 2008). Further, in animal models of HEV infection, the rise of serum transaminase levels and appearance of liver injury appears to occur simultaneous with the appearance of specific antibodies and decline in degree of viremia. These findings suggest that hepatocyte injury during HEV infection may be related to the killing of HEV-infected cells by the host immune response, rather than through a direct effect of the viral replication. It is therefore likely that the strength of the hosts's immune response determines the outcome of acute HEV infection-whether subclinical, self-limiting illness, or liver failure. In gt $3 \mathrm{HEV}$ infection, immunosuppressed people, such as those receiving immunosuppressive medications following solid-organ transplantation, often fail to clear HEV and develop chronic hepatitis E; this outcome has not yet been reported with gt $1 \mathrm{HEV}$ infection and appears to be less frequent or nonexistent.

Liver tissue obtained postmortem from patients dying of acute fulminant hepatitis $\mathrm{E}$ has shown varying degrees of hepatocyte necrosis, portal and lobular inflammation, bile ductular proliferation, lymphocytic cholangitis, Kupffer cell prominence, cholestasis, apoptotic bodies,

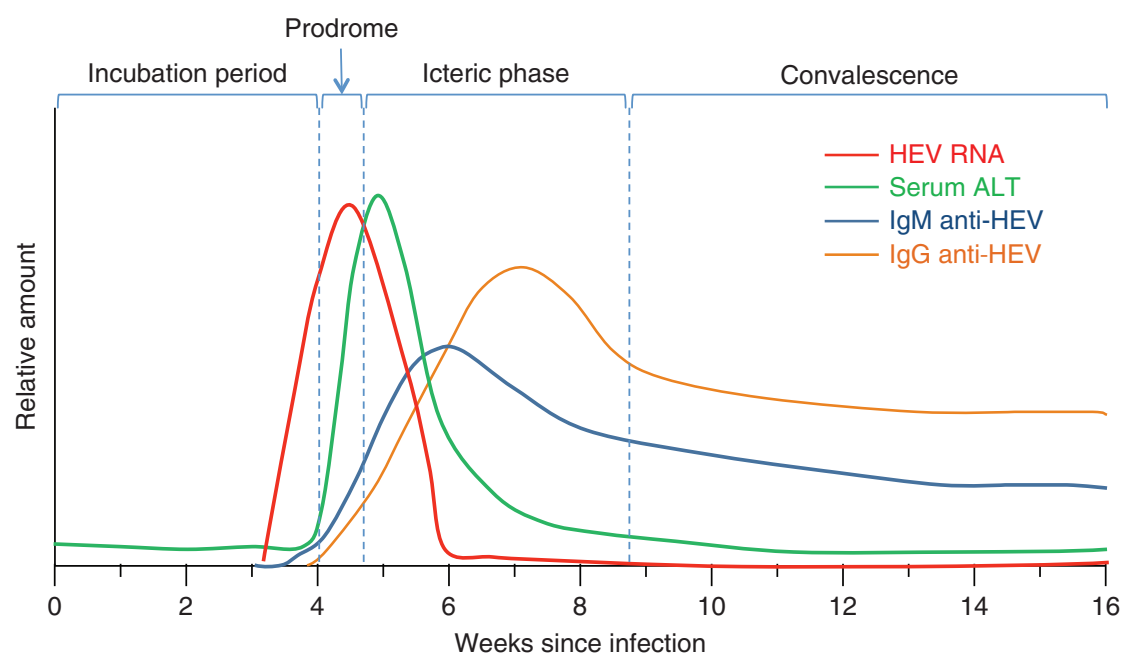

Figure 1. Time-course of events during acute infection with genotype 1 hepatitis E virus (HEV) infection. 
pseudo-rosette formation, steatosis, and presence of plasma cells in portal tracts (Agrawal et al. 2012). These changes were similar to those in patients with fulminant hepatitis $B$, except that interface hepatitis was less frequent in hepatitis E.

\section{Humoral Immune Response}

$\mathrm{HEV}$ infection leads to development of antiHEV antibodies. Immunoglobulin (Ig)M antibodies appear first, becoming detectable either late in the incubation period or briefly after the onset of symptoms; these last for nearly 4-6 months (Favorov et al. 1996; see Walker 2018). IgG antibodies appear around the same time or soon thereafter; these remain detectable for a longer period although the exact duration of their persistence remains uncertain. In one study, IgG anti-HEV antibodies were detectable in nearly half of those who had been affected during a disease outbreak 14 years earlier (Khuroo et al. 1993). However, it was not possible to negate the possibility of a re-exposure in the intervening period. Specific IgA antibodies also appear during acute HEV infection (Takahashi et al. 2005); however, their exact significance remains unclear.

In vitro studies have shown that anti-HEV antibodies can neutralize the virus. This neutralization ability applies not only to homologous strains (belonging to the same genotype), but also to heterologous isolates, which are the other $\mathrm{HEV}$ genotypes that infect humans (Zhang et al. 2012). Further, these antibodies have been shown to protect against HEV infection in experimental animals as well as humans (Zhang et al. 2012). However, because the antibody titers wane with time in at least a subset of those infected (Khuroo et al. 1993), it remains unclear how long the duration of natural protection against $\mathrm{HEV}$ reinfection lasts. Thus, HEV infection has been reported among people who previously had anti-HEV antibodies (Zhang et al. 2014).

The neutralization epitopes are located on the viral capsid protein coded by open reading frame (ORF)2 (Zhang et al. 2005, 2012). Hence, recombinant proteins corresponding to $\mathrm{HEV}$
ORF2 protein have been tried as subunit HEV vaccines. One of these vaccines, which contains a recombinant protein with amino acid sequence corresponding to a part of capsid protein of gt1 HEV, was tested in a large field trial in China, and was shown to be highly immunogenic and to protect against HEV infection (Zhang et al. 2015; see Innis and Lynch 2018). The antiHEV antibodies induced following administration of this vaccine remained detectable in a large proportion of recipients even 4.5 years after the administration of the primary three-dose schedule, although the titer declined with time (Zhang et al. 2015).

\section{Innate Immune Responses}

Normal liver is rich in cells of the innate immune system, including macrophages, natural killer (NK) cells, and natural killer T (NKT) cells. In addition, the hepatic NK cells have greater cytotoxic ability than those circulating in the blood. NK cells are known to play an important direct or indirect role in the protection against other hepatotropic viruses (see Feng and Lemon 2018). Thus, innate immune responses may reasonably be expected to help in the clearance of HEV.

We found that peripheral blood mononuclear cells (PBMCs) from Indian patients with acute hepatitis E, with human disease caused exclusively by gt1 virus, had lower proportions of NK and NKT cells than healthy subjects, but the proportions of these cells that showed evidence of activation were increased (Srivastava et al. 2008). These changes reversed during follow-up and were thought to represent preferential trafficking of NK and NKT cells to the liver, which is the main site of inflammation in HEV infection. In another study, PBMCs from patients with acute $\mathrm{HEV}$ infection showed greater interferon (IFN)- $\gamma$ production despite absence of activation of $\mathrm{HEV}$-specific $\mathrm{CD} 4^{+}$and $\mathrm{CD} 8^{+}$ cells, suggesting that NK and NKT cells could be the source of IFN- $\gamma$ (Srivastava et al. 2007, 2008).

$\mathrm{HEV}$ may itself influence the development of innate immune responses (see Feng and Lemon 2018). Thus, induction of expression of HEV ORF1 protein (of gt1 isolate) in a hepatoma cell 
line led to impaired phosphorylation of IFNregulatory factor 3 , and thus to a reduced expression of IFNs (Nan et al. 2014b). By contrast, the expression of HEV ORF3 protein in a cell line was associated with increased production of IFNs (Nan et al. 2014a).

\section{Cell-Mediated Immune Response}

Cellular immune responses play a clear role in containing viral infections. In particular, it has been shown to be important for the clearance of hepatitis $\mathrm{B}$ and $\mathrm{C}$ virus infections (Wieland and Chisari 2005), with weaker cellular immune responses being associated with increased risk of chronicity. Much less is known about the contribution of T-cell immunity to acute liver injury or control of HEV infection, particularly for gt1 and gt2 HEV infections (see Walker 2018).

In Indian patients with acute hepatitis E, enhanced proliferation of peripheral blood lymphocytes in response to HEV proteins and peptides has been shown to occur, indicating the activation of cellular immune responses (Naik et al. 2002; Srivastava et al. 2007). Similar results have also been shown among HEV-infected pregnant women (Pal et al. 2005), who are known to have particularly worse outcomes. After clinical improvement and over time, these $\mathrm{HEV}$-specific T-cell responses seem to wane, somewhat similar to the decline in anti-HEV antibody titers. The HEV-specific T-cell responses are less strong in patients with fulminant acute hepatitis $\mathrm{E}$ than in patients with milder or uncomplicated disease (Srivastava et al. 2011). However, it remains unclear whether these reduced $\mathrm{T}$-cell responses are responsible for or are the result of more severe disease outcome.

In a study of liver tissue from fatal cases with fulminant hepatitis $\mathrm{E}$ or $\mathrm{B}$ referred to above (Agrawal et al. 2012), the inflammatory cell infiltrate was similar in both diseases, being composed predominantly of $\mathrm{CD}^{+} \mathrm{T}$ cells, in particular the cytotoxic $\left(\mathrm{CD}^{+}\right)$cell subpopulation. In another study, several immune response pathways, specifically those involving cytotoxic $\mathrm{T}$ cells were activated in the livers of patients with fulminant hepatitis $\mathrm{E}$ but not those with fulminant hepatitis B (Naik et al. 2015). These data suggest that $\mathrm{CD} 8^{+} \mathrm{T}$-cell infiltration and increased gene expression of cytotoxic T-cell pathways in the liver may have a pathogenetic role in $\mathrm{HEV}$-induced liver injury.

\section{Relation of Viral Factors with Disease Severity}

Besides the host immune response, viral factors may also influence the severity of liver injury during HEV infection. In a study of full-length genomic sequences of $\mathrm{HEV}$ isolates from Indian patients, six amino acid changes (F179S, A317T, T735I, L1110F, V1120I, and F1439Y) in ORF1, which encodes viral nonstructural proteins, were identified in all patients with ALF but not in those with uncomplicated acute hepatitis $\mathrm{E}$ (Mishra et al. 2013). However, these observations were not validated in a meta-analysis of patients with AVH-E and ALF-E (Smith and Simmonds 2015). Two recent studies have led to rekindling of interest in viral factors as determinants of disease severity. One of these identified two novel mutations (C1483W and $\mathrm{N} 1530 \mathrm{~T}$ ) in the polymerase region of the HEV genome in all 25 patients with ALF and none of the patients with AVH (Borkakoti et al. 2016). The other study by the same investigators identified three novel H105R, D29N, V27A mutations in the methyltransferase region of the HEV genome in all 16 ALF patients studied but in none of a similar number with uncomplicated AVH (Borkakoti et al. 2017). However, somewhat disconcertingly, the variations associated with severe disease have varied across studies.

\section{HEV Infection during Pregnancy}

The precise mechanisms underlying the association of pregnancy and severe disease outcomes following gt1 HEV infection have not been worked out although several explanations have been proposed (Navaneethan et al. 2008; Renou et al. 2008; Pérez-Gracia et al. 2017). It is possible that this association is mediated by changes in hormonal milieu or in immune functions during pregnancy.

Pregnancy resembles somewhat a state resembling transplantation, whereby the mother's 
body tolerates the presence within it of fetus, which is a living "foreign" organ and which is genetically distinct from the "pregnant host." Therefore, it is associated with immune changes similar to those observed with immunological tolerance, or immune suppression, such as a reduction in the number and cytotoxic activity of circulating NK cells. This "acquired" partial immunosuppression may be associated with an increased risk of acquiring HEV infection on exposure, and of impaired host immunity against the virus leading to unchecked viral replication and severe disease. In this context, PBMC cells from pregnant women with acute HEV infection have been shown to have weaker lymphoproliferative responses (Pal et al. 2005). These findings are also in keeping with the observation of higher viral titers in pregnant women with $\mathrm{HEV}$ than in nonpregnant women (Kar et al. 2008; Borkakoti et al. 2013), and prolonged viremia (Begum et al. 2010).

Also, during pregnancy, the balance between the $\mathrm{T}$ helper cell (Th)1 arm of the immune response, which is involved in activation of cellular responses, and Th2 immune response, which is involved more in activation of humoral immune responses, is known to tilt in favor of the latter (Pal et al. 2005). The Th1 arm plays a role in clearing several viral infections, including $\mathrm{HBV}$ and $\mathrm{HCV}$ viruses, and in the induction of liver injury in infection with these hepatotropic viruses. Therefore, a bias toward Th2 response during pregnancy may allow for an increased rate of HEV multiplication in the host liver and thus greater liver injury.

Pregnancy is associated with excess of several circulating hormones, for example, progesterone, estrogen, and human chorionic gonadotropin. These hormones may influence cellular immune responses, and hence the outcome of HEV infection. For instance, in one study, addition of sera derived from pregnant women enhanced the in vitro replication of HEV by suppressing estrogen receptors and type I IFNs (Bi et al. 2015). Another study suggested that reduced expression of progesterone receptor and of a progesterone-induced blocking factor (Bose et al. 2011) contributed to the severe HEV-related liver injury in pregnant women.
A role of viral factors has also been suggested because HEV infection in pregnant women in Egypt has been reported not to be associated with ALF despite gt1 being the dominant genotype (Stoszek et al. 2006a). This suggests that different strains of gt1 HEV may have a different propensity to cause severe disease during pregnancy.

The adverse effect of HEV on the fetus could result indirectly from the maternal illness, from a compromise of the placental function, or from the transplacental infection of the fetus itself.

\section{Extrahepatic Manifestations}

The most plausible mechanism for nonhepatic organs involvement is indirect immune-mediated injury and is unlikely to be related to direct pathogenic effect of HEV (Wedemeyer and Cornberg 2016). Such immune-mediated injury could be caused either by anti-HEV antibodies through immune-complex deposition or crossreactivity with a native auto-antigen, which gets either exposed or modified because of HEV infection.

HEV RNA has indeed been detected in cerebrospinal fluid (CSF) of some patients with gt3 HEV infection and neurological manifestations (Dalton et al. 2016). Also, several neuronal cell lines have been shown to support replication of HEV; this capability appears to be stronger for gt3 HEV than for gt1 HEV (Drave et al. 2016). This has been suggested as an explanation for the more frequent occurrence of neurological manifestations with gt3 HEV infection than with gt1 virus (Wedemeyer and Cornberg 2016). However, HEV has not been looked for in the CSF of patients with gt1 HEV infection and neurological illness.

Mechanisms postulated for occurrence of pancreatic inflammation, the most common form of extrahepatic involvement reported with gt1 HEV infection, have included hypotension and ischemia, intrapancreatic hemorrhage secondary to deranged coagulation, drugs, sepsis, oxidative stress, and multiorgan dysfunction syndrome (Raj et al. 2015). Unfortunately, no studies have been performed to look for 
replication of $\mathrm{HEV}$ in the pancreatic tissue, to clarify the role of viral multiplication within this organ in this injury.

\section{CONCLUDING REMARKS}

Infections with gt 1 or gt $2 \mathrm{HEV}$ are highly prevalent in several parts of Asia and Africa and cause significant morbidity in the form of outbreaks and sporadic cases of acute viral hepatitis. The illness often lasts a few weeks but is generally self-limiting. However, a few cases, particularly those with pregnancy or preexisting liver disease, develop ALF, a severe disease with high risk of mortality.

Although the exact pathogenesis of liver injury has not been worked out, host immune responses appear to play a significant role. Further work is needed to understand the effect of pregnancy on outcomes of gt 1 or gt $2 \mathrm{HEV}$ infection, and to develop and test interventions to prevent the adverse outcome of this infection in pregnant women.

\section{REFERENCES}

${ }^{*}$ Reference is also in this collection.

Abid S, Khan AH. 2002. Severe hemolysis and renal failure in glucose-6-phosphate dehydrogenase deficient patients with hepatitis E. Am J Gastroenterol 97: 1544-1547.

Acharya SK, Panda SK, Saxena A, Gupta SD. 2000. Acute hepatic failure in India: A perspective from the East. $J$ Gastroenterol Hepatol 15: 473-479.

Aggarwal R. 2010. The global prevalence of hepatitis E virus infection and susceptibility: A systematic review. World Health Organization, Geneva.

Aggarwal R. 2011. Clinical presentation of hepatitis E. Virus Res 161: 15-22.

Aggarwal R. 2013. Hepatitis E: Clinical presentation in disease-endemic areas and diagnosis. Semin Liver Dis 33: 30-40.

Aggarwal R, Goel A. 2016. Advances in hepatitis E. I: Virology, pathogenesis and diagnosis. Expert Rev Gastroenterol Hepatol 10: 1053-1063.

Aggarwal R, Naik S. 2009. Epidemiology of hepatitis E: Current status. J Gastroenterol Hepatol 24: 1484-1493.

Aggarwal R, Kini D, Sofat S, Naik SR, Krawczynski K. 2000. Duration of viraemia and faecal viral excretion in acute hepatitis E. Lancet 356: 1081-1082.

Agrawal V, Goel A, Rawat A, Naik S, Aggarwal R. 2012. Histological and immunohistochemical features in fatal acute fulminant hepatitis E. Indian J Pathol Microbiol 55: $22-27$.
Ali G, Kumar M, Bali SK, Wadhwa WB. 2001. Hepatitis E associated immune thrombocytopenia and membranous glomerulonephritis. Indian J Nephrol 11: 70-72.

Anty R, Ollier L, Peron JM, Nicand E, Cannavo I, Bongain A, Giordanengo V, Tran A. 2012. First case report of an acute genotype 3 hepatitis $\mathrm{E}$ infected pregnant woman living in South-Eastern France. J Clin Virol 54: 76-78.

Bazerbachi F, Haffar S, Garg SK, Lake JR. 2016. Extra-hepatic manifestations associated with hepatitis E virus infection: A comprehensive review of the literature. Gastroenterol Rep (Oxf) 4: 1-15.

Bazerbachi F, Leise MD, Watt KD, Murad MH, Prokop LJ, Haffar S. 2017. Systematic review of mixed cryoglobulinemia associated with hepatitis E virus infection: Association or causation? Gastroenterol Rep (Oxf) 5: 178-184.

Begum N, Polipalli SK, Husain SA, Kumar A, Kar P. 2010. Duration of hepatitis E viremia in pregnancy. Int J Gynaecol Obstet 108: 207-210.

Bhagat S, Wadhawan M, Sud R, Arora A. 2008. Hepatitis viruses causing pancreatitis and hepatitis: A case series and review of literature. Pancreas 36: 424-427.

Bhatia V, Singhal A, Panda SK, Acharya SK. 2008. A 20-year single-center experience with acute liver failure during pregnancy: Is the prognosis really worse? Hepatology 48: 1577-1585.

Bi Y, Yang C, Yu W, Zhao X, Zhao C, He Z, Jing S, Wang H, Huang F. 2015. Pregnancy serum facilitates hepatitis E virus replication in vitro. J Gen Virol 96: 1055-1061.

Borkakoti J, Hazam RK, Mohammad A, Kumar A, Kar P. 2013. Does high viral load of hepatitis $\mathrm{E}$ virus influence the severity and prognosis of acute liver failure during pregnancy? J Med Virol 85: 620-626.

Borkakoti J, Ahmed G, Kar P. 2016. Report of a novel $\mathrm{C} 1483 \mathrm{~W}$ mutation in the hepatitis $\mathrm{E}$ virus polymerase in patients with acute liver failure. Infect Genet Evol 44: 51-54.

Borkakoti J, Ahmed G, Rai A, Kar P. 2017. Report of novel H105R, D29N, V27A mutations in the methyltransferase region of the $\mathrm{HEV}$ genome in patients with acute liver failure. J Clin Virol 91: 1-4.

Bose PD, Das BC, Kumar A, Gondal R, Kumar D, Kar P. 2011. High viral load and deregulation of the progesterone receptor signaling pathway: Association with hepatitis E-related poor pregnancy outcome. J Hepatol 54: 1107-1113.

Dalton HR, Bendall RP, Keane FE, Tedder RS, Ijaz S. 2009. Persistent carriage of hepatitis E virus in patients with HIV infection. N Engl J Med 361: 1025-1027.

Dalton HR, Kamar N, van Eijk JJ, McLean BN, Cintas P, Bendall RP, Jacobs BC. 2016. Hepatitis E virus and neurological injury. Nat Rev Neurol 12: 77-85.

Drave SA, Debing Y, Walter S, Todt D, Engelmann M, Friesland M, Wedemeyer H, Neyts J, Behrendt P, Steinmann E. 2016. Extra-hepatic replication and infection of hepatitis E virus in neuronal-derived cells. J Viral Hepat 23: 512 521.

Favorov MO, Khudyakov YE, Mast EE, Yashina TL, Shapiro CN, Khudyakova NS, Jue DL, Onischenko GG, Margolis HS, Fields HA. 1996. IgM and IgG antibodies to hepatitis $\mathrm{E}$ virus (HEV) detected by an enzyme immunoassay 
based on an HEV-specific artificial recombinant mosaic protein. J Med Virol 50: 50-58.

* Feng Z, Lemon SM. 2018. Innate immunity to enteric hepatitis viruses. Cold Spring Harb Perspect Med doi: 10.1101/ cshperspect.a033464.

Fix AD, Abdel-Hamid M, Purcell RH, Shehata MH, AbdelAziz F, Mikhail N, el Sebai H, Nafeh M, Habib M, Arthur RR, et al. 2000. Prevalence of antibodies to hepatitis E in two rural Egyptian communities. Am J Trop Med Hyg 62: 519-523.

Goel A, Aggarwal R. 2016. Advances in hepatitis E. II: Epidemiology, clinical manifestations, treatment and prevention. Expert Rev Gastroenterol Hepatol 10: 1065-1074.

Huang CC, Nguyen D, Fernandez J, Yun KY, Fry KE, Bradley DW, Tam AW, Reyes GR. 1992. Molecular cloning and sequencing of the Mexico isolate of hepatitis $\mathrm{E}$ virus (HEV). Virology 191: 550-558.

* Innis BL, Lynch JA. 2018. Immunization against hepatitis E. Cold Spring Harb Perspect Med doi: 10.1101/cshperspect. a032573.

Jaroszewicz J, Flisiak R, Kalinowska A, Wierzbicka I, Prokopowicz D. 2005. Acute hepatitis E complicated by acute pancreatitis: A case report and literature review. Pancreas 30: $382-384$.

Joshi GG, Thakur BS, Sircar S, Namdeo A, Jain AK. 2009. Role of intravenous naloxone in severe pruritus of acute cholestasis. Indian J Gastroenterol 28: 180-182.

* Kamar N, Pischke S. 2018. Acute and persistent hepatitis E virus genotype 3 and 4 infection: Clinical features, pathogenesis, and treatment. Cold Spring Harb Perspect Med doi: 10.1101/cshperspect.a031872.

Kamar N, Selves J, Mansuy JM, Ouezzani L, Peron JM, Guitard J, Cointault O, Esposito L, Abravanel F, Danjoux M, et al. 2008. Hepatitis E virus and chronic hepatitis in organ-transplant recipients. N Engl J Med 358: 811-817.

Kamar N, Bendall RP, Peron JM, Cintas P, Prudhomme L, Mansuy JM, Rostaing L, Keane F, Ijaz S, Izopet J, et al. 2011. Hepatitis E virus and neurologic disorders. Emerg Infect Dis 17: 173-179.

Kamar N, Bendall R, Legrand-Abravanel F, Xia NS, Ijaz S, Izopet J, Dalton HR. 2012. Hepatitis E. Lancet 379: 24772488.

Kamar N, Marion O, Abravanel F, Izopet J, Dalton HR. 2016. Extrahepatic manifestations of hepatitis E virus. Liver Int 36: $467-472$.

Kar P, Jilani N, Husain SA, Pasha ST, Anand R, Rai A, Das BC. 2008. Does hepatitis E viral load and genotypes influence the final outcome of acute liver failure during pregnancy? Am J Gastroenterol 103: 2495-2501.

Khuroo MS. 1980. Study of an epidemic of non-A, non-B hepatitis. Possibility of another human hepatitis virus distinct from post-transfusion non-A, non-B type. Am J Med 68: 818-824.

Khuroo MS, Kamili S. 2003. Aetiology and prognostic factors in acute liver failure in India. J Viral Hepat 10: 224231.

Khuroo MS, Teli MR, Skidmore S, Sofi MA, Khuroo MI. 1981. Incidence and severity of viral hepatitis in pregnancy. Am J Med 70: 252-255.
Khuroo MS, Kamili S, Dar MY, Moecklii R, Jameel S. 1993. Hepatitis E and long-term antibody status. Lancet 341: 1355.

Khuroo MS, Kamili S, Jameel S. 1995. Vertical transmission of hepatitis E virus. Lancet 345: 1025-1026.

Kim JH, Nelson KE, Panzner U, Kasture Y, Labrique AB, Wierzba TF. 2014. A systematic review of the epidemiology of hepatitis E virus in Africa. BMC Infect Dis 14: 308.

Kochar NS, Sehgal B, Solomon L. 2016. Acute pancreatitis and myocarditis: A rare complication of acute hepatitis $\mathrm{E}$ infection. J Assoc Physicians India 64: 111.

Krain LJ, Atwell JE, Nelson KE, Labrique AB. 2014. Fetal and neonatal health consequences of vertically transmitted hepatitis E virus infection. Am J Trop Med Hyg 90: 365370.

Kumar A, Aggarwal R, Naik SR, Saraswat V, Ghoshal UC, Naik S. 2004. Hepatitis E virus is responsible for decompensation of chronic liver disease in an endemic region. Indian J Gastroenterol 23: 59-62.

Kumar Acharya S, Kumar Sharma P, Singh R, Kumar Mohanty S, Madan K, Kumar Jha J, Kumar Panda S. 2007. Hepatitis E virus (HEV) infection in patients with cirrhosis is associated with rapid decompensation and death. $J$ Hepatol 46: 387-394.

Lee GH, Tan BH, Teo EC, Lim SG, Dan YY, Wee A, Aw PP, Zhu Y, Hibberd ML, Tan CK, et al. 2016. Chronic infection with camelid hepatitis E Virus in a liver transplant recipient who regularly consumes camel meat and milk. Gastroenterology 150: 355-357 e353.

Lu L, Li C, Hagedorn CH. 2006. Phylogenetic analysis of global hepatitis E virus sequences: Genetic diversity, subtypes and zoonosis. Rev Med Virol 16: 5-36.

Mechnik L, Bergman N, Attali M, Beergabel M, Mosenkis B, Sokolowski N, Malnick S. 2001. Acute hepatitis E virus infection presenting as a prolonged cholestatic jaundice. J Clin Gastroenterol 33: 421-422.

Meng XJ. 2013. Zoonotic and foodborne transmission of hepatitis E virus. Semin Liver Dis 33: 41-49.

Meng XJ, Halbur PG, Haynes JS, Tsareva TS, Bruna JD, Royer RL, Purcell RH, Emerson SU. 1998. Experimental infection of pigs with the newly identified swine hepatitis E virus (swine HEV), but not with human strains of HEV. Arch Virol 143: 1405-1415.

Mishra A, Saigal S, Gupta R, Sarin SK. 1999. Acute pancreatitis associated with viral hepatitis: A report of six cases with review of literature. Am J Gastroenterol 94: 2292 2295.

Mishra P, Mahapatra M, Kumar R, Pati HP. 2007. Autoimmune hemolytic anemia and erythroid hypoplasia associated with hepatitis E. Indian J Gastroenterol 26: 195196.

Mishra N, Walimbe AM, Arankalle VA. 2013. Hepatitis E virus from India exhibits significant amino acid mutations in fulminant hepatic failure patients. Virus Genes 46: 47-53.

Munjal S, Gupta N, Sharma RK, Gupta A, Prasad N, Kaul A, Bhadauria D, Goel A, Aggarwal R. 2014. Lack of persistent hepatitis $\mathrm{E}$ virus infection as a cause for unexplained transaminase elevation in renal transplant recipients in India. Indian J Gastroenterol 33: 550-553. 
Naik SR, Aggarwal R, Salunke PN, Mehrotra NN. 1992. A large waterborne viral hepatitis E epidemic in Kanpur, India. Bull World Health Organ 70: 597-604.

Naik S, Aggarwal R, Naik SR, Dwivedi S, Talwar S, Tyagi SK, Duhan SD, Coursaget P. 2002. Evidence for activation of cellular immune responses in patients with acute hepatitis E. Indian J Gastroenterol 21: 149-152.

Naik A, Gupta N, Goel D, Ippagunta SK, Sharma RK, Aggarwal R. 2013. Lack of evidence of hepatitis E virus infection among renal transplant recipients in a diseaseendemic area. J Viral Hepat 20: e138-e140.

Naik A, Goel A, Agrawal V, Sarangi AN, Chhavi N, Singh V, Jameel S, Aggarwal R. 2015. Changes in gene expression in liver tissue from patients with fulminant hepatitis $\mathrm{E}$. World J Gastroenterol 21: 8032-8042.

Nan Y, Ma Z, Wang R, Yu Y, Kannan H, Fredericksen B, Zhang YJ. 2014a. Enhancement of interferon induction by ORF3 product of hepatitis E virus. J Virol 88: 86968705.

Nan Y, Yu Y, Ma Z, Khattar SK, Fredericksen B, Zhang YJ. 2014b. Hepatitis E virus inhibits type I interferon induction by ORF1 products. J Virol 88: 11924-11932.

Navaneethan U, Al Mohajer M, Shata MT. 2008. Hepatitis E and pregnancy: Understanding the pathogenesis. Liver Int 28: $1190-1199$.

Ollier L, Tieulie N, Sanderson F, Heudier P, Giordanengo V, Fuzibet JG, Nicand E. 2009. Chronic hepatitis after hepatitis $\mathrm{E}$ virus infection in a patient with non-Hodgkin lymphoma taking rituximab. Ann Intern Med 150: 430431.

Pal R, Aggarwal R, Naik SR, Das V, Das S, Naik S. 2005. Immunological alterations in pregnant women with acute hepatitis E. J Gastroenterol Hepatol 20: 1094-1101.

Patel RC, Kamili S, Teshale E. 2015. Hepatitis E virus infections in children age $0-15$, Uganda outbreak, 2007. J Clin Virol 73: 112-114

Patra S, Kumar A, Trivedi SS, Puri M, Sarin SK. 2007. Maternal and fetal outcomes in pregnant women with acute hepatitis E virus infection. Ann Intern Med 147: 28-33.

Pérez-Gracia MT, Suay-Garcia B, Mateos-Lindemann ML. 2017. Hepatitis E and pregnancy: Current state. Rev Med Virol doi: 10.1002/rmv.1929.

Radha Krishna Y, Saraswat VA, Das K, Himanshu G, Yachha SK, Aggarwal R, Choudhuri G. 2009. Clinical features and predictors of outcome in acute hepatitis $A$ and hepatitis $\mathrm{E}$ virus hepatitis on cirrhosis. Liver Int 29: 392-398.

Raj M, Kumar K, Ghoshal UC, Saraswat VA, Aggarwal R, Mohindra S. 2015. Acute hepatitis E-associated acute pancreatitis: A single center experience and literature review. Pancreas 44: 1320-1322.

Renou C, Pariente A, Nicand E, Pavio N. 2008. Pathogenesis of hepatitis E in pregnancy. Liver Int 28: 1465; author reply 1466.

Renou C, Gobert V, Locher C, Moumen AO, Timbely O, Savary J, Roque-Afonso AM. 2014. Prospective study of hepatitis E virus infection among pregnant women in France. Virol J 11: 68.

Singh NK, Gangappa M. 2007. Acute immune thrombocytopenia associated with hepatitis $\mathrm{E}$ in an adult. $\mathrm{Am} \mathrm{J}$ Hematol 82: 942-943.
Singh A, Seth R, Gupta A, Shalimar, Nayak B, Acharya SK, Das P. 2016. Chronic hepatitis E-An emerging disease in an immunocompromised host. Gastroenterol Rep (Oxf) doi: 10.1093/gastro/gow024.

Smith DB, Simmonds P. 2015. Hepatitis E virus and fulminant hepatitis-A virus or host-specific pathology? Liver Int 35: 1334-1340.

Srivastava R, Aggarwal R, Jameel S, Puri P, Gupta VK, Ramesh VS, Bhatia S, Naik S. 2007. Cellular immune responses in acute hepatitis $\mathrm{E}$ virus infection to the viral open reading frame 2 protein. Viral Immunol 20: 56-65.

Srivastava R, Aggarwal R, Bhagat MR, Chowdhury A, Naik S. 2008. Alterations in natural killer cells and natural killer T cells during acute viral hepatitis E. J Viral Hepat 15: 910 916.

Srivastava R, Aggarwal R, Sachdeva S, Alam MI, Jameel S, Naik S. 2011. Adaptive immune responses during acute uncomplicated and fulminant hepatitis E. J Gastroenterol Hepatol 26: 306-311.

Stoszek SK, Abdel-Hamid M, Saleh DA, El Kafrawy S, Narooz S, Hawash Y, Shebl FM, El Daly M, Said A, Kassem E, et al. 2006a. High prevalence of hepatitis $\mathrm{E}$ antibodies in pregnant Egyptian women. Trans R Soc Trop Med Hyg 100: $95-101$.

Stoszek SK, Engle RE, Abdel-Hamid M, Mikhail N, AbdelAziz F, Medhat A, Fix AD, Emerson SU, Purcell RH, Strickland GT. 2006b. Hepatitis E antibody seroconversion without disease in highly endemic rural Egyptian communities. Trans R Soc Trop Med Hyg 100: 89-94.

Tabatabai J, Wenzel JJ, Soboletzki M, Flux C, Navid MH, Schnitzler P. 2014. First case report of an acute hepatitis E subgenotype 3 c infection during pregnancy in Germany. J Clin Virol 61: 170-172.

Takahashi M, Kusakai S, Mizuo H, Suzuki K, Fujimura K, Masuko K, Sugai Y, Aikawa T, Nishizawa T, Okamoto H 2005. Simultaneous detection of immunoglobulin A (IgA) and IgM antibodies against hepatitis $\mathrm{E}$ virus (HEV) is highly specific for diagnosis of acute HEV infection. J Clin Microbiol 43: 49-56.

Takahashi M, Yamada K, Hoshino Y, Takahashi H, Ichiyama K, Tanaka T, Okamoto H. 2008. Monoclona antibodies raised against the ORF3 protein of hepatitis $\mathrm{E}$ virus (HEV) can capture HEV particles in culture supernatant and serum but not those in feces. Arch Virol 153: 1703-1713.

Tanaka T, Takahashi M, Kusano E, Okamoto H. 2007. Development and evaluation of an efficient cell-culture system for hepatitis E virus. J Gen Virol 88: 903-911.

Teshale EH, Howard CM, Grytdal SP, Handzel TR, Barry V, Kamili S, Drobeniuc J, Okware S, Downing R, Tappero JW, et al. 2010. Hepatitis E epidemic, Uganda. Emerg Infect Dis 16: 126-129.

Ticehurst J, Rhodes LL Jr, Krawczynski K, Asher LV, Engler WF, Mensing TL, Caudill JD, Sjogren MH, Hoke CH Jr, LeDuc JW, et al. 1992. Infection of owl monkeys (Aotus trivirgatus) and cynomolgus monkeys (Macaca fascicularis) with hepatitis E virus from Mexico. J Infect Dis 165: $835-845$.

Tsarev SA, Emerson SU, Reyes GR, Tsareva TS, Legters LJ, Malik IA, Iqbal M, Purcell RH. 1992. Characterization of a prototype strain of hepatitis E virus. Proc Natl Acad Sci 89: 559-563. 
Tsega E, Krawczynski K, Hansson BG, Nordenfelt E, Negusse Y, Alemu W, Bahru Y. 1991. Outbreak of acute hepatitis $\mathrm{E}$ virus infection among military personnel in northern Ethiopia. J Med Virol 34: 232-236.

Tsega E, Hansson BG, Krawczynski K, Nordenfelt E. 1992. Acute sporadic viral hepatitis in Ethiopia: Causes, risk factors, and effects on pregnancy. Clin Infect Dis 14: 961-965.

van Bijnen ST, Ledeboer M, Martens HA. 2017. Chronic hepatitis $\mathrm{E}$ in a patient with rheumatoid arthritis treated with adalimumab and methotrexate. Rheumatology (Oxford) 56: 497-498.

Velazquez O, Stetler HC, Avila C, Ornelas G, Alvarez C, Hadler SC, Bradley DW, Sepulveda J. 1990. Epidemic transmission of enterically transmitted non-A, non-B hepatitis in Mexico, 1986-1987. JAMA 263: 32813285.

Viswanathan R. 1957. Infectious hepatitis in Delhi (195556): A critical study: Epidemiology. Indian J Med Res 45: $1-29$.

Viswanathan R, Sidhu AS. 1957. Infectious hepatitis; clinical findings. Indian J Med Res 45: 49-58.

* Walker CM. 2018. Adaptive immune responses to hepatitis A virus and hepatitis E virus infections. Cold Spring Harb Perspect Med doi: 10.1101/cshperspect.a033472.

Wedemeyer H, Cornberg M. 2016. The hepatitis E virus: A likely cause of extrahepatic diseases! Liver Int 36: 473476.
Wedemeyer H, Rybczynska J, Pischke S, Krawczynski K. 2013. Immunopathogenesis of hepatitis $E$ virus infection. Semin Liver Dis 33: 71-78.

Wieland SF, Chisari FV. 2005. Stealth and cunning: Hepatitis B and hepatitis C viruses. J Virol 79: 9369-9380.

Woolson KL, Forbes A, Vine L, Beynon L, McElhinney L, Panayi V, Hunter JG, Madden RG, Glasgow T, Kotecha A, et al. 2014. Extra-hepatic manifestations of autochthonous hepatitis E infection. Aliment Pharmacol Ther 40: 1282-1291.

Zhai L, Dai X, Meng J. 2006. Hepatitis E virus genotyping based on full-length genome and partial genomic regions. Virus Res 120: 57-69.

Zhang J, Gu Y, Ge SX, Li SW, He ZQ, Huang GY, Zhuang H, Ng MH, Xia NS. 2005. Analysis of hepatitis E virus neutralization sites using monoclonal antibodies directed against a virus capsid protein. Vaccine 23: 2881-2892.

Zhang J, Li SW, Wu T, Zhao Q, Ng MH, Xia NS. 2012. Hepatitis E virus: Neutralizing sites, diagnosis, and protective immunity. Rev Med Virol 22: 339-349.

Zhang J, Zhang XF, Zhou C, Wang ZZ, Huang SJ, Yao X, Liang ZL, Wu T, Li JX, Yan Q, et al. 2014. Protection against hepatitis $\mathrm{E}$ virus infection by naturally acquired and vaccine-induced immunity. Clin Microbiol Infect 20: O397-O405.

Zhang J, Zhang XF, Huang SJ, Wu T, Hu YM, Wang ZZ, Wang H, Jiang HM, Wang YJ, Yan Q, et al. 2015. Longterm efficacy of a hepatitis E vaccine. $N$ Engl J Med 372: 914-922. 


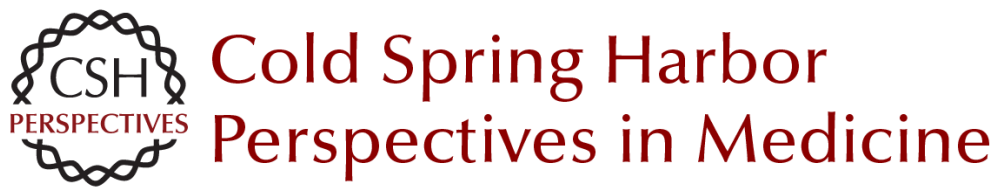

\section{Natural History, Clinical Manifestations, and Pathogenesis of Hepatitis E Virus Genotype 1 and 2 Infections}

Rakesh Aggarwal and Amit Goel

Cold Spring Harb Perspect Med 2019; doi: 10.1101/cshperspect.a032136 originally published online May 7, 2018

\section{Subject Collection Enteric Hepatitis Viruses}

Hepatitis A Virus Genome Organization and

Replication Strategy

Kevin L. McKnight and Stanley M. Lemon

Adaptive Immune Responses in Hepatitis A Virus and Hepatitis E Virus Infections Christopher M. Walker

Small Animal Models of Hepatitis E Virus Infection Tian-Cheng Li and Takaji Wakita

Acute and Persistent Hepatitis E Virus Genotype 3 and 4 Infection: Clinical Features, Pathogenesis, and Treatment

Nassim Kamar and Sven Pischke

Epidemiology of Genotype 1 and 2 Hepatitis E

Virus Infections

Kenrad E. Nelson, Alain B. Labrique and Brittany L. Kmush

History of the Discovery of Hepatitis A Virus Stephen M. Feinstone

Epidemiology and Transmission of Hepatitis A Virus and Hepatitis E Virus Infections in the United States

Megan G. Hofmeister, Monique A. Foster and Eyasu H. Teshale

Stem Cell-Derived Culture Models of Hepatitis E Virus Infection Viet Loan Dao Thi, Xianfang Wu and Charles M. Rice
Evolutionary Origins of Enteric Hepatitis Viruses Anna-Lena Sander, Victor Max Corman, Alexander N. Lukashev, et al.

Enterically Transmitted Non-A, Non-B Hepatitis and the Discovery of Hepatitis E Virus Stanley M. Lemon and Christopher M. Walker

Natural History, Clinical Manifestations, and

Pathogenesis of Hepatitis E Virus Genotype 1 and 2 Infections

Rakesh Aggarwal and Amit Goel

Hepatitis A Virus and Hepatitis E Virus: Emerging and Re-Emerging Enterically Transmitted

Hepatitis Viruses

Stanley M. Lemon and Christopher M. Walker

Hepatitis A Virus Capsid Structure

David I. Stuart, Jingshan Ren, Xiangxi Wang, et al.

Comparative Pathology of Hepatitis A Virus and

Hepatitis E Virus Infection John M. Cullen and Stanley M. Lemon

Innate Immunity to Enteric Hepatitis Viruses Zongdi Feng and Stanley M. Lemon

Nonhuman Primate Models of Hepatitis A Virus and Hepatitis E Virus Infections

Robert E. Lanford, Christopher M. Walker and Stanley M. Lemon

For additional articles in this collection, see http://perspectivesinmedicine.cshlp.org/cgi/collection/ 